УДК 343.102 (477)

\title{
СПЕЦИФІКА ПРАВОВОГО СТАТУСУ СВІДКА В КРИМІНАЛЬНОМУ ПРОЦЕСІ УКРАЇНИ
}

Харітонова М. В.

Стаття присвячена аналізу норм чинного кримінального процесуального законодавства України з питань правового статусу такого учасника кримінального процесу, як свідок. Визначено, що статус свідка в кримінальному процесі є важливим явищем, оскільки саме цей суб'єкт є одним з основних носіїв доказової інформації. Визначено систему нормативних приписів, які створюють умови, що забезпечують свідку якісну підготовку й викладення даних щодо обставин, які є предметом допиту.

Досліджено права, обов'язки й відповідальність свідка за чинним Кримінальним процесуальним кодексом України. Визначено, що процесуальні права й обов'язки свідка як елементи правового статусу перебувають на одній паралелі, спрямовані на досягнення єдиної мети - залучення свідка до кримінального процесу. Констатовано, що в кримінальному провадженні критерієм для визначення обов'язків свідка є забезпечення особи, яка є свідком у кримінальному провадженні, нормативними приписами поведінки, що спрямована на сприяння реалізації юридично значущих публічних і приватних інтересів, пов'язаних із притягненням особи, яка вчинила кримінальне правопорушення, до кримінальної відповідальності шляхом спонукання їі до повідомлення тільки правдивих відомостей про факти, які мають значення для кримінального провадження, та утримання їі від протидії досудовому розслідуванню й судовому розгляду. Визначено проблемні аспекти статусу свідка в кримінальному провадженні.

Ключові слова: суб'єкти кримінального прочесу, свідок, правовий статус, процесуальне становище, кримінально-процесуальні правовідносини, права, обов'язки.

Статья посвящена анализу норм действующего уголовного процессуального законодательства Украины относительно вопросов, касающихся правового статуса такого участника уголовного процесса, как свидетель. Oпределено, что статус свидетеля в уголовном процессе является важным явлением, поскольку именно этот субъект один из основных носителей доказательной информации. Определена система нормативных предписаний, которые создают условия, обеспечивающие свидетелю качественную подготовку и изложение показаний об обстоятельствах, являющихся предметом допроса.

Исследованы права, обязанности и ответственность свидетеля по действующему Уголовно-процессуальному кодексу Украины. Определено, что процессуальные права и обязанности свидетеля как элементы правового статуса находятся на одной параллели и направлены на достижение единой цели - участия свидетеля в уголовном процессе. Констатировано, что в уголовном производстве критерием для определения обязанностей свидетеля является обеспечение лица, являющегося свидетелем в уголовном производстве, нормативными предписаниями поведения, направленного на содействие реализации юридически значимых публичных и частных интересов, связанных с привлечением лица, совершившего уголовное преступление, $\kappa$ уголовной ответственности путем побуждения его $к$ сообщению только правдивых сведений о фактах, имеющих значение для уголовного производства, и воздержа ния его от противодействия досудебному расследованию и судебному разбирательству. Определены проблемные аспекты статуса свидетеля в уголовном производстве.

Ключевые слова: субъекты уголовного процесса, свидетель, правовой статус, процессуальное положение, уголовно-процессуальные правоотношения, права, обязанно$\mathrm{cmu}$.

The article is devoted the analysis of norms of the operating Criminal Procedural Code of Ukraine in relation to legal status of such participant of criminal process as a witness. Determination of status of witness in a criminal process is the important phenomenon, as exactly he is the basic carrier of evidential data.

It is determined that the procedure of criminal justice should ensure not only the inevitability of criminal punishment, but also guarantee the proper observance of human rights in the criminal process, respect for his personality, treatment of him as a person guilty of a crime not yet committed, and also ensure impartiality and objectivity of pre-trial investigation and trial, provide for effective procedures that will provide equal procedural capacity for the prosecution and defense and will provide a real statement of the competitiveness of the criminal process.

It is determined that legal status is a system of socially acceptable, statutory and guaranteed by the state authority of a person's capacity as a subject of legal relations. The rights and responsibilities of the witness - the elements of legal status - are in one parallel, both the first and the second aiming at achieving the sole purpose of involving a witness in criminal proceedings - obtaining the facts necessary to decide a criminal proceeding.

The legislative definition of the system of normative prescriptions is analyzed, which, first of all, creates the conditions that provide the witness with qualitative preparation and presentation of data on the circumstances that are the subject of questioning; secondly, they provide the opportunity to be free to decide on the content of testimony in morally difficult situations when the circumstances referred to in paragraph 3 of Part 1 of Article 1 are the subject of questioning. 66 of the CCP, or where there are threats to its security; thirdly, they are able to evaluate the legal implications of their testimony with the involvement of a lawyer and to obtain legal assistance from him in respect of witness rights in criminal proceedings; fourth, provide the witness with the accuracy of the witness's perceptions of the perceptions of the witness.

The duties of a witness, who ensure that he receives factual information about the circumstances relevant to the criminal proceedings, are considered as follows: 1) to give truthful testimony during the pre-trial investigation and trial; 2) not to disclose without the permission of the investigator, the prosecutor, the court information directly related to the nature of the criminal proceedings and the procedural actions carried out (carried out) during him and which became known to the witness in connection with the performance of his duties.

The classification of the immunity of a witness, which reveals its various aspects as a multilateral purpose in criminal proceedings, is intended to balance the public interest in establishing

Харітонова М. В., 2019 
the truth in criminal proceedings and the need to safeguard the private interests of the individual.

Therefore, consideration of the general theoretical framework for defining the concept of legal status allows us to draw the following conclusions: the legal status of a person is a system of socially permissible, statutory and guaranteed by the state authority of a person's capacity as a subject of legal relations; the content and structure of the legal status, as a legal category, should include only rights and obligations; the legal status of a witness is a sectoral type of legal status, that is, the status of a subject of legal relations governed by the rules of criminal procedure.

Key words: subjects of criminal proceedings, witness, legal status, procedural status, criminal procedural relations, rights, obligations.

Постановка проблеми та її актуальність. Одним із важливих аспектів існування України як правової держави й здійснення в ній правових реформ $\epsilon$ створення умов, які забезпечують можливість реалізації прав і свобод людей для відстоювання своїх законних інтересів. Особливої уваги заслуговує такий учасник кримінального процесу, як свідок, адже це суб'єкт, якого найчастіше залучають до досудового розслідування й судового розгляду кримінальних проваджень. Він $€$ основним носієм доказової інформації, тому значення свідка для досягнення мети кримінального судочинства важко переоцінити.

Аналіз норм Кримінального процесуального кодексу України (далі - КПК) показує, що більшість законодавчих формулювань, які висвітлюють механізм реалізації систем гарантій прав учасників кримінального провадження, стосується прав або особи, яка підозрюється, обвинувачується в учиненні кримінального правопорушення або постраждала від нього. Це може призвести до хибного висновку, що регуляторна спрямованість засад кримінального провадження зосереджена на забезпеченні прав I законних інтересів тих учасників, які відстоюють власний інтерес у кримінальному провадженні. Однак під час уважнішого дослідження правового механізму реалізації процесуального статусу учасників кримінального провадження, які сприяють досягненню його завдань, можна побачити суттєвий вплив на вказаний процес системи засад кримінального судочинства [1, с. 295].

Ю.П. Аленін та Ю.О. Гурджі зазначають, що сучасна теорія держави й права, теорія прав людини, конституційне право, теорія кримінального процесу виокремлюють становище особи та її інтереси в «структурі цінностей» держави й переорієнтацію правозастосовної практики на природно-правові цінності з метою забезпечення побудови правової держави [2, с. 30]. Реформаційні процеси в цій ланці у сфері кримінального судочинства, на думку Ю.М. Грошевого, мають охоплювати створення такого кримінально-процесуального механізму, за якого належним чином забезпечується баланс публічних і приватних інтересів, адже кримінальне судочинство здійснюється в інтересах суспільства загалом і кожної людини зокрема [3, с. 6]. КПК є підтвердженням цілеспрямованого руху законодавця до забезпечення пріоритету дотримання основоположних прав людини.

Порядок здійснення кримінального судочинства має забезпечувати не лише невідворотність кримінального покарання, а й гарантувати належне дотримання прав людини в кримінальному процесі, повагу до її особисто- сті, ставлення до неї як до особи, вина якої у вчиненні злочину ще не доведена, а також забезпечувати неупередженість й об'єктивність досудового розслідування й судового розгляду, передбачати існування ефективних процедур, які надаватимуть рівні процесуальні можливості стороні обвинувачення і стороні захисту й сприятимуть реальному утвердженню змагальності кримінального процесу [4].

Аналіз останніх досліджень і публікацій. За останні роки в наукових виданнях опубліковано низку статей, де розглядалися окремі права й обов'язки свідка, їх зміст і дискусійні моменти. Окремі сторони участі свідка в кримінальному процесі висвітлювались у роботах М.С. Алексєєва, С.А. Альперта, В.П. Бож'єва, П.С. Елькінда, М.В. Жогіна, Д.С. Карєва, Л.М. Карнєєвої, В.А. Стрємовського, М.С. Строговича, Ю.М. Грошевого, В.С. Зеленецького, Г.К. Кожевнікова, В.І. Мариніва, М.М. Міхеєнка, О.Р. Михайленка, М.Є. Шумила, Ю.П. Яновича та інших. Водночас інститут участі свідка в кримінальному судочинстві не вивчався з огляду на зміни в кримінальному процесуальному законодавстві, переважно його вивчення стосується доказового значення показань свідка в кримінальному судочинстві. Отже, об'єктивно виникла необхідність в комплексній роботі з дослідження особливостей правового статусу свідка в кримінальному процесі України.

Метою статті $\epsilon$ виокремлення та аналіз правового статусу свідка у кримінальному провадженні України, визначення його прав та обов'язків, а також визначення факторів, які обумовлюють специфіку правового статусу свідка в кримінальному процесі України.

Виклад основного матеріалу. Правовий статус свідка $\epsilon$ багатокомпонентною категорією, погляди на зміст якої $є$ різноманітними. Однак усі науковці одностайно стверджують, що права й обов'язки свідка становлять його основу [5, с. 16-18; 6, с. 879-880].

Визначення поняття «правовий статус» у науці не $\epsilon$ однозначним. Переважна більшість запропонованих у літературі визначень цього поняття зроблена шляхом вказівки на структурні елементи цієї категорії без урахування самої сутності явища. У цьому аспекті найбільш повною вважаємо думку, висловлену М.В. Вітруком: «Правовий статус - це соціально припустимі й необхідні можливості, потенції особи не просто як індивіда, а як громадянина держави. Вони гарантовані авторитетом держави, всією його силою» [7, с. 8]. Загалом підтримуючи цю думку, зауважимо, що категорію правового статусу слід розглядати через призму правовідносин, в яких бере участь особа, адже лише під час виконання певних дій з реалізації наданих їй можливостей особа реалізує свій статус як суб'єкта правовідносин. Наділення учасників правовідносин певними можливостями таким чином виступає одним з етапів механізму правового регулювання. Гадаємо, термін «можливості» має охоплювати як можливості виконати власні дії, так і можливості вимагати від інших суб'єктів виконання певних дій, тобто це поняття пояснює як права, так і обов'язки учасників правовідносин. Виходячи з цього, вважаємо, що правовий статус - це система соціально припустимих, нормативно закріплених і гарантованих авторитетом держави можливостей особи як суб'єкта правовідносин.

СТ. 66 КПК містить перелік процесуальних прав й обов'язків свідка. Як зазначає В.М. Трофименко, права й обов'язки свідка - елементи правового ста- 
тусу, що перебувають на одній паралелі, спрямовані на досягнення єдиної мети - залучення свідка до кримінального процесу й отримання фактичних даних, необхідних для вирішення справи [8, с. 85].

Свідок має такі права: 1) право знати, у зв'язку з чим і в якому кримінальному провадженні він допитується; 2) користуватися під час давання показань й участі в проведенні інших процесуальних дій правовою допомогою адвоката, повноваження якого підтверджуються згідно з положеннями ст. 50 КПК; 3) відмовитися давати показання щодо себе, близьких родичів і членів своєі сім'ї, що можуть стати підставою для підозри, обвинувачення в учиненні ним, близькими родичами чи членами його сім'ї кримінального правопорушення, а також показання щодо відомостей, які згідно з положеннями ст. 65 КПК не підлягають розголошенню; 4) давати показання рідною або іншою мовою, якою він вільно володіє, і користуватися допомогою перекладача; 5) користуватися нотатками й документами під час давання показань у тих випадках, коли показання стосуються будь-яких розрахунків та інших відомостей, які йому важко утримувати в пам'яті; 6) ознайомлюватися з протоколом допиту й заявляти клопотання про внесення до нього змін, доповнень і зауважень, а також власноручно робити такі доповнення й зауваження; 7) заявляти клопотання про забезпечення безпеки у випадках, передбачених законом; 8) заявляти відвід перекладачу [9].

3 переліку цих прав очевидно, що законодавець визначає систему нормативних приписів, які, по-перше, створюють умови, що забезпечують свідку якісну підготовку й викладення даних щодо обставин, які $\epsilon$ предметом допиту; по-друге, забезпечують можливість бути вільним у прийнятті рішення щодо змісту показань у морально складних ситуаціях, коли предметом допиту виступають обставини, які наведені у п. 3 ч. 1 ст. 66 КПК, або коли є загрози його безпеці; по-третє, дають можливість оцінювати з залученням адвоката правові наслідки своїх показань й одержувати правову допомогу від нього з питань дотримання прав свідка в кримінальному провадженні; по-четверте, забезпечують контроль свідком точності сприйняття суб'єктом, який здійснює допит, відомостей, які повідомляє свідок [10, с. 107].

Як правильно зазначає В.Т. Нор, особа набуває процесуального статусу свідка з моменту виклику їі для допиту у визначеному законом порядку [11]. Однак, у ст. 112 КПК, у якій визначено зміст повідомлення, не вказано як його обов'язковий елемент поряд із процесуальним статусом, у якому перебуває особа, іï процесуальні права. Те саме стосується й змісту повістки про виклик, який викладено у ст. 137 КПК. Тому погоджуємося з Ю.І. Лозинською, що з метою забезпечення умов для більш якісної підготовки осіб до участі в процесуальних діях, зокрема й до допитів свідків, необхідно п. 5 ч. 1 ст. 112 КПК та п. 5 ч. 1 ст. 137 КПК доповнити приписом щодо наведення в повідомленні, повістці щодо участі особи в процесуальній дії їі процесуальних прав й обов'язків [10, с. 107].

До нормативно встановлених обов'язків свідка, які забезпечують одержання від нього фактичних даних про обставини, які мають значення для кримінального провадження, належать такі: 1) давати правдиві показання під час досудового розслідування й судового розгляду; 2) не розголошувати без дозволу слідчого, прокурора, суду відомості, які безпосередньо стосу- ються суті кримінального провадження й процесуальних дій, що здійснюються (здійснювалися) під час нього і які стали відомі свідку у зв'язку з виконанням його обов'язків.

У теорії права категорія «обов'язки» розглядається як парна до категорії права особи, оскільки обов'язок $\epsilon$ способом забезпечення права, як вид і міра необхідної поведінки, що вимагається законом і відповідає праву (повноваженню) іншої особи [12, с. 137]. Використання особою своїх прав одночасно передбачає їі обов'язок захищати й зміцнювати ці права заради себе й задля інших [13, с. 70]. У кримінальному провадженні критерієм для визначення обов'язків свідка $\epsilon$ забезпечення нормативними приписами поведінки особи, яка $€$ свідком у кримінальному провадженні, що спрямована на сприяння реалізації юридично значущих публічних i приватних інтересів, пов'язаних із притягненням особи, яка вчинила кримінальне правопорушення, до кримінальної відповідальності шляхом спонукання ії до повідомлення тільки правдивих відомостей про факти, які мають значення для кримінального провадження, й утримання її від протидії досудовому розслідуванню й судовому розгляду.

Виконання свідком своїх обов'язків перебуває в площині його правосвідомості. Але з огляду на те, що поведінка свідка може бути і соціально корисною, і соціально шкідливою, законодавець передбачив у ст. ст. 384, 385, 387 Кримінального кодексу України кримінальну відповідальність свідка за надання свідомо неправдивого показання, відмову від надання показань і за розголошення даних досудового розслідування.

Реалізація обов'язків свідка перебуває в площині дії таких гарантій, як імунітет свідка. У науковій літературі під «імунітетом свідка» розуміють безумовне (абсолютне) чи за умови (відносне) звільнення перелічених у законі груп фізичних осіб від обов'язку давати показання про відомі їм обставини, які мають значення для кримінального провадження [11; 14, с. 71-72; 15, с. 96-102]. Класифікація імунітету свідка проводиться за такими ознаками:

- за колом дії - загальний, тобто право свідка не свідчити проти себе й своїх близьких родичів, перелік яких зазначений у п. 1 ч. 1 ст. 3 КПК (ст. 63 Конституції України, п. 3 ч. 1 ст. 66 КПК), і спеціальні імунітети осіб, професійний статус яких зобов' язує зберігати в таємниці відомості, одержані в результаті їхньої професійної діяльності [16, с. 126];

за наявності в особи, яка допитується, суб'єктивного права відмовитися від давання показань як свідка, а також наявності або відсутності заборони у відповідних уповноважених органів допитувати цих осіб - на альтернативний, коли в особи $\epsilon$ вибір скористатися своїм суб'єктивним правом чи ні (наприклад, близькі родичі підозрюваного); безальтернативний, коли у свідка $\epsilon$ право відмовитися від давання показань і слідчому заборонено допитувати цю особу, навіть коли вона бажає дати такі показання (наприклад, захисник підозрюваного) [17]; особистий безпосередній імунітет свідка, тобто такий, який гарантується ст. 63 Конституції України; опосередкований законний імунітет свідка, тобто імунітет осіб, на яких законом покладено обов'язок зберігати в таємниці отриману ними інформацію [16, с. 127];

залежно від змісту показань, щодо яких у свідка $\epsilon$ право їх не давати, - право свідка відмовитися від 
давання показань задля реалізації свободи від самозвинувачення; імунітет свідків стосовно показань щодо близьких родичів і членів сім'ї; імунітет свідків стосовно охоронюваної законом таємниці [15, с. 99].

Наведені класифікації розкривають різні аспекти імунітету свідка як багатостороннього за своїм призначенням у кримінальному провадженні правового явища, яке покликане збалансувати суспільний інтерес у встановленні істини в кримінальному провадженні й потребою у збереженні приватних інтересів особистості [18, с. 195], гармонізувати категорії совісті, милосердя, сімейних цінностей з імперативністю в процесуальній формі кримінального провадження загалом і проведення окремих слідчих (розшукових) дій (далі - С(Р)Д). Відповідно до нормативних приписів ч. 2, 4 ст. 65 КПК не можуть бути допитані як свідки такі особи: 1) захисник, представник потерпілого, цивільного позивача, цивільного відповідача, юридичної особи, щодо якої здійснюється провадження, законний представник потерпілого, цивільного позивача в кримінальному провадженні (про обставини, які стали їм відомі у зв'язку з виконанням функцій представника чи захисника); 2) адвокати (про відомості, які становлять адвокатську таємницю); 3) нотаріуси (про відомості, які становлять нотаріальну таємницю); 4) медичні працівники та інші особи, яким у зв'язку з виконанням професійних або службових обов'язків стало відомо про хворобу, медичне обстеження, огляд та їх результати, інтимну й сімейну сторони життя особи (про відомості, які становлять лікарську таємницю); 5) священнослужителі (про відомості, одержані ними на сповіді вірян); 6) журналісти (про відомості, які містять конфіденційну інформацію професійного характеру, надану за умови нерозголошення авторства або джерела інформації); 7) професійні судді, народні засідателі й присяжні (про обставини обговорення в нарадчій кімнаті питань, що виникли під час ухвалення судового рішення за винятком випадків кримінального провадження щодо прийняття суддею/суддями свідомо неправосудного вироку, ухвали; 8) особи, які брали участь в укладенні й виконанні угоди про примирення в кримінальному провадженні (про обставини, які стали їм відомі у зв'язку з участю В укладенні й виконанні угоди про примирення); 9) особи, до яких застосовані заходи безпеки (щодо дійсних даних про таких осіб); 10) особи, які мають відомості про дійсні дані про осіб, до яких застосовані заходи безпеки (щодо цих даних); 11) особи, які мають право дипломатичної недоторканності (без їхньої згоди), а також працівники дипломатичних представництв (без згоди представника дипломатичної установи) [9].

Показання свідків визнаються одним з головних видів доказів, а участь свідка у доказуванні обставин кримінального провадження має вирішальне значення [19, с. 99]. Відповідно до ч. 1 ст. 65 КПК свідком є фізична особа, якій відомі або можуть бути відомі обставини, що підлягають доведенню під час кримінального провадження, i яка викликана для давання показань.

Законодавець, формулюючи легальну дефініцію свідка, як і будь-яку іншу дефініцію, у такий спосіб завжди намагається сформувати основу для єдиних поглядів на конкретні правові явища й процеси, для розкриття змісту й сутності яких вони введені в текст нормативно-правового акта. Позитив у цьому очевидний, але завжди $\epsilon$ й ризик того, що через неточності в легальній дефініції може виникнути неоднозначне розуміння тексту нормативно-правового акта, а відтак неоднаковою може бути й правозастосовна практика. Такі неточності вбачаємо й у легальній дефініції свідка. Зокрема, законодавець у ч. 1 ст. 65 КПК наголошує на тому, що свідок $є$ носієм відомостей про обставини, які підлягають доказуванню під час кримінального провадження. Однак під час досудового розслідування як свідків допитують осіб, яким відомі обставини переховування особи, яка підозрюється у вчиненні кримінального правопорушення, і ці відомості необхідні для прийняття процесуальних рішень й організації розшуку такої особи. Також предметом допиту може бути місцеперебування майна, яке підлягає конфіскації чи спеціальній конфіскації. Навіть якщо припустити, що факт переховування підозрюваного (обвинуваченого) можна розглядати як такий, що характеризує особу обвинуваченого, тобто підпадає під п. 4 ч. 1 ст. 91 КПК, то відомості про місцеперебування майна, яке підлягає конфіскації чи спеціальній конфіскації, що забезпечують його розшук і накладення на нього арешту, не відповідають п. 6 ч. 1 ст. 91 КПК. Також згідно з абзацом 4 ч. 7 ст. 223 КПК поняті, тобто учасники процесуальної дії, які засвідчують хід, порядок і результати проведення певної дії, щодо цього можуть бути допитані як свідки під час судового розгляду. На можливість допиту осіб, які проводили негласні слідчі (розшукові) дії або були залучені до їх проведення як свідки, вказує й норма ч. 2 ст. 256 КПК. Зазначимо також, що як свідків у суді нерідко допитують і слідчих, співробітників оперативних підрозділів та інших співробітників правоохоронних органів, осіб, які брали участь у С(Р)Д як спеціалісти [10, с. 103-104].

Під час допиту може бути одержана інформація, яка має значення для розв'язання розшукових завдань, важливих для досудового розслідування, і подальшого судового розгляду кримінальної справи, а також відомості, що дають можливість оцінити додержання процесуальної форми проведення процесуальної дії й відповідність її результатів, відображених у протоколі процесуальної дії й додатках до нього, шляхом зіставлення з показаннями осіб про ії хід і результати.

Отже, розгляд загальних теоретичних засад щодо визначення поняття правового статусу дає змогу зробити такі висновки:

- правовий статус особи - це система соціально припустимих, нормативно закріплених і гарантованих авторитетом держави можливостей особи як суб'єкта правовідносин;

- зміст і структура правового статусу як правової категорії мають містити лише права й обов'язки;

- правовий статус свідка є галузевим видом правовогостатусу, тобто статусом суб' єктаправовідносин, урегульованих нормами кримінально-процесуального права.

\section{Література}

1. Кучинська О.П. Процесуальний статус свідків: деякі особливості за новим КПК України. Юридичний часопис національної академії внутрішніх справ, № 1, 2013. С. 295-299.

2. Аленін Ю., Гурджі Ю. Публічна природа гарантій прав особи в кримінальному процесі. Право України. 2003. № 4. С. 30-32.

3. Грошевий Ю.М. Проблеми реформування кримінального судочинства. Право України. 2009. № 2. С. 4-10. 


\section{Організаційно-правові аспекти досудового слідства}

4. Пояснювальна записка до проєкту Кримінального процесуального кодексу. URL: http://w1.c1.rada.gov.ua/ pls/zweb2/webproc4_2?id=\&pf3516=9700\&skl=7.

5. Белькова О.В. Правовий статус свідка в кримінальному процесі України: дис. ... канд. юрид. наук ; Харківський національний університет внутрішніх справ. Харків, 2005. 223 c.

6. Слінько С.В. Процесуальний статус свідка в кримінальному процесі. Форум права. 2012. № 1. С. 878-882. URL: http://www.irbisnbuv.gov.ua/cgibin/irbis_nbuv/ cgiirbis_64.exe?I21DBN=LINK\&P21DBN=UJRN\&Z21ID=\&S21.

7. Витрук Н.В. Правовой статус личности в СССР. Москва, 1985. 176 с.

8. Трофименко В.М. Кримінально-процесуальні гарантії особистості в стадії судового розгляду : дис. ... канд. юрид. наук : 12.00 .09 ; Національна юридична академія імені Ярослава Мудрого ; Харків, 2000. 228 с.

9. Кримінальний процесуальний кодекс України : [від 13 квітня 2012 р. № 4651-VI] : станом на 12 червня 2019 р. URL: https://zakon.rada.gov.ua/laws/show/4651-17\#n2921.

10. Лозинська Ю.І. Достовірність показань свідка та ії 3'ясування у кримінальному провадженні : дис. ... канд. юрид. наук. Львів, 2018. 259 с.

11. Нор В.Т. Свідок у кримінальному процесі України: коло осіб, предмет показань та свідоцький імунітет. Радник : український юридичний портал. URL: http://radnuk.info/home/24839c.html.

12. Теория права и государства / под ред. проф. Г.Н. Манова. Москва : Изд-во БЕК, 1996. 336 с.
13. Скакун О.Ф. Теорія держави і права : підручник. Київ : Алерта КНТ ЦУЛ, 2009. 520 с.

14. Стахівський С. Проблеми імунітету свідків у кримінально-процесуальному законодавстві. Право України. 1995. № 9. С. 71-72.

15. Волкотруб С.Г. Імунітет у кримінальному процесі України : монографія. Харків : Консум, 2005. 144 с.

16. Веселов М.Ю., Заремба Т.С., Олешицька В.Е. Інститут імунітету свідка в кримінально-процесуальному праві. Юридичний науковий електронний журнал. 2016. № 3. C. 124-128. URL: http:///sej.org.ua/3_2016/ 38.pdf.

17. Вельш И.В. Свидетельский иммунитет в уголовном процессе : автореф. дисс. ... на соискание уч. степени канд. юрид. наук : 12.00.09. Москва : Академия управления МВД России, 2000. 20 с. URL: http://www.law.edu.ru/ article/article. asp?articlelD=1291153.

18. Денисенко Г.В. Поняття та класифікація імунітету свідків за кримінальним процесуальним законодавством. Науковий вісник Міжнародного гуманітарного університету. Серія «Юриспруденція». 2016. № 23. С. 195-197.

19. Панасюк Т.І. Захист свідків і потерпілих у кримінальному процесі України : автореф. дис. ... канд. юрид. наук. Київ, 2009. 22 с.

Харітонова М. В., аспірант кафедри кримінального процесу Одеського державного університету внутрішніх справ 